\title{
Estimation Models of Variance Components for Farrowing Interval in Swine
}

\author{
Aderbal Cavalcante Neto $^{1 *}$, Jeffrey Frederico Lui ${ }^{2}$, José Lindenberg Rocha Sarmento ${ }^{3}$, \\ Maria Norma Ribeiro ${ }^{4}$, José Mauro Costa Monteiro ${ }^{5}$, Carlos Fonseca ${ }^{6}$ and Humberto \\ Tonhati $^{2}$ \\ ${ }^{I}$ Departamento de Zootecnia; Faculdade de Ciências Agrárias e Veterinárias de Jaboticabal; Universidade \\ Estadual Paulista Júlio de Mesquita Filho; 14884-900; Jaboticabal - SP - Brasil. ${ }^{2}$ Departamento de Zootecnia; \\ Universidade Estadual Paulista; Jaboticabal - SP - Brasil. ${ }^{3}$ Universidade Federal do Piauí; Bom Jesus - PI - Brasil. \\ ${ }^{4}$ Departamento de Zootecnia; Universidade Federal Rural de Pernambuco; Recife - PE - Brasil. ${ }^{5}$ Escola \\ Agrotécnica Federal de Muzambinho; Muzambinho - MG - Brasil. ${ }^{6}$ Departamento de Biologia; CESAM; \\ Universidade de Aveiro; Aveiro - Portugal
}

\begin{abstract}
The main objective of this study was to evaluate the importance of including maternal genetic, common litter environmental and permanent environmental effects in estimation models of variance components for the farrowing interval trait in swine. Data consisting of 1,013 farrowing intervals of Dalland (C-40) sows recorded in two herds were analyzed. Variance components were obtained by the derivative-free restricted maximum likelihood method. Eight models were tested which contained the fixed effects(contemporary group and covariables) and the direct genetic additive and residual effects, and varied regarding the inclusion of the maternal genetic, common litter environmental, and/or permanent environmental random effects. The likelihood-ratio test indicated that the inclusion of these effects in the model was unnecessary, but the inclusion of the permanent environmental effect caused changes in the estimates of heritability, which varied from 0.00 to 0.03 . In conclusion, the heritability values obtained indicated that this trait appears to present no genetic gain as response to selection. The common litter environmental and the maternal genetic effects did not present any influence on this trait. The permanent environmental effect, however, should be considered in the genetic models for this trait in swine, because its presence caused changes in the additive genetic variance estimates.
\end{abstract}

Key words: Common litter, maternal effect, permanent environment, heritability, repeatability, swine

\section{INTRODUCTION}

For a genetic improvement program to be successful, the right statistical models must be used for estimating genetic parameters in the population. Thus, the models must cover both the genetic and the environment effects, which can affect the productive and reproductive traits of swine (Arouca et al., 2004; Arouca et al., 2005; Oliveira et al., 2005; Pires et al., 2005; Fraga et al., 2008; Pires et al., 2008). In the particular case of reproductive traits, there is no agreement in the literature as to which random effects should be utilized in the model for a real estimation of the

\footnotetext{
*Author for correspondence: aderbalcavalcante@gmail.com
} 
genetic parameters of these traits in swine, and therefore individual evaluations have been necessary for each specific situation.

Maternal effects accounted for a significant amount of the variance for most traits in swine, including those manifested late in the animals' life (Robinson, 1972; Irgang et al., 1994; Kaufmann et al., 2000; Johnson et al., 2002; Chen et al., 2002; Chimonyo et al., 2006; Rydhmer et al., 2008).

In addition, when members of the same family are raised together, like piglets, they share a common environment which contributes to their resemblance. Consequently, there is additional covariance among them, increasing the variances among different families. The origin of common environmental variances among families could be due to similar nutrition and/or climatic conditions (Mrode, 1996). Lately, several works have used the common litter environmental effect in the models for better estimation of variance components, including those of reproductive traits (Kaufmann et al., 2000; Zhang et al., 2000; Lukovic et al., 2003; Lukovic et al., 2004; Chimonyo et al., 2006).

Thus, a model that deals with maternal genetic, common litter environmental and direct genetic effects should provide more precise genetic parameter estimates for reproductive traits in swine than a model that contains only direct genetic effect (Roehe and Kennedy, 1993; Pires, 1999; Cavalcante Neto, 2006; Torres Filho et al., 2005).

The main objective of this study was to evaluate the importance of including the maternal genetic, common litter environmental and permanent environmental effects in the estimation model of variance components of the farrowing interval in swine.

\section{MATERIALS AND METHODS}

Data consisting of 1,013 farrowing intervals of Dalland (C-40) sows recorded in two herds were analyzed. Some animals belonged to the São José Farm - Canalli Brothers (herd 1), located in Monte Alto, State of São Paulo, Brazil, and others to the São José Farm (herd 2), located in Cabo Verde, State of Minas Gerais, Brazil.

The animals were all kept in the conventional installations made of cement-coated brick walls with impermeable floors, with pickets in the designated reproduction units. A commercially available feed was supplied to the breeding stock, meeting the nutritional requirements of all the phases of raising.

With the intent of obtaining more consistent data, some restrictions were adopted in the analyses. For instance, only information of sows which were the daughters of sires with at least three daughters and of dams with at least two were considered. It was also defined that the contemporary groups should include at least four observations. After the restrictions were made, 1,013 farrowing intervals of 1 to 7 farrowings of 347 sows, the daughters of 10 sires and 97 dams, were recorded.

Estimates of the variance components were obtained by the derivative-free restricted maximum likelihood method (Kaufmann et al., 2000; Torres Filho et al., 2005; Sarmento et al., 2006; Chiorato et al., 2008), using the MTDFREML software (Boldman et al., 1995) applied to animal models. The trait was analyzed by several single-trait models.

A simplex variance of values (-2 $\log _{\mathrm{e}}$ of likelihood) lower than $10^{-9}$ was used as convergence criterion. After each convergence, the program was restarted, with the estimates of the previous apparent convergence used as initial values, until an apparent global minimum was found and the estimates of genetic parameters did not change between runs.

In the analyses, eight models were used with different combinations of random effects:

$$
\begin{aligned}
& \text { Model 1: } \mathrm{y}=\mathrm{Xb}+\mathrm{Z}_{1} \mathrm{~d}+\mathcal{E} \\
& \text { Model 2: } \mathrm{y}=\mathrm{Xb}+\mathrm{Z}_{1} \mathrm{~d}+\mathrm{Z}_{4} \mathrm{p}+\mathcal{E} ; \\
& \text { Model 3: } \mathrm{y}=\mathrm{Xb}+\mathrm{Z}_{1} \mathrm{~d}+\mathrm{Z}_{2} \mathrm{~m}+\mathcal{E} ; \\
& \text { Model 4: } \mathrm{y}=\mathrm{Xb}+\mathrm{Z}_{1} \mathrm{~d}+\mathrm{Z}_{3} \mathrm{c}+\mathcal{E} \\
& \text { Model 5: } \mathrm{y}=\mathrm{Xb}+\mathrm{Z}_{1} \mathrm{~d}+\mathrm{Z}_{2} \mathrm{~m}+\mathrm{Z}_{4} \mathrm{p}+\mathcal{E} ; \\
& \text { Model 6: } \mathrm{y}=\mathrm{Xb}+\mathrm{Z}_{1} \mathrm{~d}+\mathrm{Z}_{3} \mathrm{c}+\mathrm{Z}_{4} \mathrm{p}+\mathcal{E} \\
& \text { Model 7: } \mathrm{y}=\mathrm{Xb}+\mathrm{Z}_{1} \mathrm{~d}+\mathrm{Z}_{2} \mathrm{~m}+\mathrm{Z}_{3} \mathrm{c}+\mathcal{E}_{;} \mathrm{e} \\
& \text { Model 8: } \mathrm{y}=\mathrm{Xb}+\mathrm{Z}_{1} \mathrm{~d}+\mathrm{Z}_{2} \mathrm{~m}+\mathrm{Z}_{3} \mathrm{c}+\mathrm{Z}_{4} \mathrm{p}+\mathcal{E} .
\end{aligned}
$$
in which:

$\mathrm{y}$ is the observation vector; $X$, fixed effects incidence matrix; $b$, fixed effects vector; $Z_{1}$, direct genetic additive effects incidence matrix; $d$, direct genetic additive effects vector; $Z_{2}$, maternal genetic effects incidence matrix; $\mathrm{m}$, maternal genetic effects vector; $Z_{3}$, common litter effects incidence matrix; c, common litter environmental effects vector; $Z_{4}$, permanent environmental effects incidence matrix; $p$, permanent environmental effects vector; and $\varepsilon$, residual effects. 
It was assumed that vectors $\mathrm{d}, \mathrm{m}, \mathrm{c}, \mathrm{p}$ and $\mathcal{E}$ have a normal distribution, with $\mathrm{E}(\mathrm{d})=\mathrm{E}(\mathrm{m})=\mathrm{E}(\mathrm{c})=$ $\mathrm{E}(\mathrm{p})=\mathrm{E}(\varepsilon)=0$ and $\operatorname{Var}(\mathrm{d})=A \sigma_{d}^{2}, \operatorname{Var}(\mathrm{m})=$ $A \sigma_{m}^{2}, \operatorname{Var}(\mathrm{c})=I_{n} \sigma_{c}^{2}, \operatorname{Var}(\mathrm{p})=I_{N p} \sigma_{p}^{2}, \operatorname{Var}(\varepsilon)=$ $I_{N} \sigma_{e}^{2}$, where $\sigma_{d}^{2}, \sigma_{m}^{2}, \sigma_{c}^{2}, \sigma_{p}^{2}$, and $\sigma_{e}^{2}$ are the

direct genetic additive, maternal genetic, common litter environmental, permanent environmental and residual variances, respectively; $\mathrm{A}$ is Wright's kinship coefficient matrix between the animals; $I_{n}$ is an identity matrix of order $n$, where $n$ is the number of litters; $\mathrm{I}_{\mathrm{Np}}$ is an identity matrix of order $\mathrm{Np}$, where $\mathrm{Np}$ is the number of sows with repeated measurements; and $\mathrm{I}_{\mathrm{N}}$ is the identity matrix of order $\mathrm{N}$, where $\mathrm{N}$ is the total number of observations.

The co-variances among the genetic and the environmental effects, among the environmental effects, plus among the direct and maternal genetic effects were assumed as being zero.

The fixed effect considered in the analysis was the contemporary group, formed by farrowing year $(2000, \ldots, 2004)$, farrowing season $(1,2,3$ and 4), and herd (1 and 2). Lactation length and weaningto-estrus interval, both in the linear form, were used as co-variables (Cavalcante Neto et al., 2008a).

The likelihood function logarithm $\left(\log _{\mathrm{e}} \mathrm{L}\right)$ was used to determine the most appropriate models for the trait. A random effect was considered to have an expressive influence when its inclusion caused significant increases in $\log _{\mathrm{e}} \mathrm{L}$. To determine the most adequate model, the likelihood-ratio test (LR) was applied in reduced sequence models (Rao, 1973). The LR was used to determine the significance of model $\mathrm{i}$, containing an additional parameter, compared to the other model, $\mathrm{j}$, in which this parameter was not present. The value was, at that time, two times less than the natural logarithm of the likelihood-ratio test:

$\mathrm{LR}_{\mathrm{ij}}=-2 \log _{\mathrm{e}}\left(\mathrm{L}_{\mathrm{j}} / \mathrm{L}_{\mathrm{i}}\right)=2 \log _{\mathrm{e}} \mathrm{L}_{\mathrm{i}}-2 \log _{\mathrm{e}} \mathrm{L}_{\mathrm{j}}$ in which:

$\mathrm{L}_{\mathrm{j}}=$ maximum restricted likelihood for model $\mathrm{j}$; and $\mathrm{L}_{\mathrm{i}}=$ maximum restricted likelihood for model i.

The value obtained for the statistical likelihoodratio test (LR) was then compared with the chisquare table $\left(\chi_{\text {tab }}^{2}\right)$ with a certain degree of freedom, and the conclusions were reached as follows: if $L R>\chi_{\text {tab }}^{2}$, the effect was considered to have a significant influence. The maximum level of significance used was $5 \%$.

\section{RESULTS AND DISCUSSION}

Table 1 presents the variance component estimates for the farrowing interval, obtained by single-trait models, as well as the logarithm values of the likelihood function $\left(\log _{\mathrm{e}} \mathrm{L}\right)$ for each model.

Table 1 shows that the inclusion of the maternal genetic effect (model 3) did not increase $\log _{\mathrm{e}} \mathrm{L}$ when compared to the value obtained by the model that used only the additive genetic effect (model 1). Likewise, there were no differences in the values of $\log _{\mathrm{e}} \mathrm{L}$ when the common litter environmental effect was added (model 4), nor with the combination of this effect with the maternal genetic effect (model 7). It is therefore not necessary to include these effects in the genetic assessment models for this trait.

However, when the permanent environmental effect (Model 2) was included, $\log _{\mathrm{e}} \mathrm{L}$ increased, but, according to the likelihood-ratio test, not significantly when compared to the model that considered only the additive genetic effect (Model $1)$.

Regarding the combinations of random effects (Models 5, 6 and 7), none of them caused a significant increase in $\log _{\mathrm{e}} \mathrm{L}$ when compared with the models which considered, besides the additive, each effect in an isolated manner (models 2, 3 and 4). The combinations which stood out were those of the permanent environmental, maternal genetic and common litter environmental effects (models 6 and 7): although these models presented an increase in $\log _{\mathrm{e}} \mathrm{L}$ compared to models 3 and 4 , this increase was not significant either, compared to the one which included only the permanent environmental effect (model 2). Hence, model 2 presented virtually the same $\log _{\mathrm{e}} \mathrm{L}$ as models 6 and 7 , indicating that the inclusion of any other effect is not necessary.

Similarly, Kerr and Cameron (1995) did not find evidence either of maternal genetic effects on traits that manifest late in the animal's life, like litter size and birth weight. They pointed out that there were few estimates of maternal genetic effects, even though the literature suggested that the relative importance of the maternal effect for a specific population depends both on the data structure and on the method of analysis.

Torres Filho et al. (2001) also observed that, when, besides the additive genetic, other effects such as the maternal genetic or common litter environmental effect were included in the 
evaluation of the total piglets born and live piglets born traits, as well as the litter weight at birth, their inclusion did not produce a significant difference.

Pires et al. (1999), however, compared the use of four models with different combinations of random effects for the genetic evaluation of weight traits of the litter at birth and at 21 days of age and the mortality rate of swine of the Landrace, Large White and Duroc breeds, and found, using the likelihood-ratio test, that the complete model that included the direct, maternal genetic and common litter environmental effects was the most adequate for the majority of the traits.

It is known that in mammals the mothers exert a greater effect than the fathers on the phenotype of the offspring because, in addition to their genetic contribution, they can influence the offspring by means of the environment they provide them. Thus, especially until weaning, the growth traits are determined by two genotypes: that of the animal itself (direct genetic effect) and that of its mother (maternal genetic effect) (Pires and Lopes, 2001). However, even though it was not observed in the present work, some authors found a significant maternal effect on traits which are expressed late in the animal's life, such as the reproductive traits (Irgang et al., 1994; Kerr and Cameron, 1995; Kaufmann et al., 2000; Torres Filho et al., 2005; Torres Filho et al., 2006; Chimonyo et al., 2006; Rydhmer et al., 2008).

Table 1 - Estimates of variance components, restricted maximum likelihood function logarithm values (logeL), and likelihood ratio test (LR) values for the farrowing interval trait, according to the analysis model.

\begin{tabular}{|c|c|c|c|c|c|c|c|}
\hline \multirow[b]{2}{*}{ Model } & \multicolumn{6}{|c|}{ Parameter } & \multirow[b]{2}{*}{$\log _{e} L$} \\
\hline & $\sigma_{a}^{2}$ & $\sigma_{m}^{2}$ & $\sigma_{c}^{2}$ & $\sigma_{p}^{2}$ & $\sigma_{e}^{2}$ & $\sigma_{f}^{2}$ & \\
\hline 1 & 0.966 & - & - & - & 38.230 & 39.20 & -4404.76 \\
\hline 2 & 0.000 & - & - & 2.640 & 36.440 & 39.09 & -4401.45 \\
\hline 3 & 1.005 & 0.004 & - & - & 38.099 & 39.10 & -4404.76 \\
\hline \multirow[t]{2}{*}{4} & 1.004 & - & 0.002 & - & 38.096 & 39.10 & -4404.76 \\
\hline & & & & & & & $\begin{aligned} \mathrm{LR}^{21} & =3.31^{\mathrm{ns}} \\
\mathrm{LR}^{31} & =0.00^{\mathrm{ns}} \\
\mathrm{LR}^{41} & =0.00^{\text {ns }}\end{aligned}$ \\
\hline 5 & 0.007 & 0.122 & - & 2.788 & 36.191 & 39.10 & -4401.55 \\
\hline 6 & 0.000 & - & 0.000 & 2.863 & 36.263 & 39.12 & -4401.47 \\
\hline \multirow[t]{2}{*}{7} & 0.612 & 0.108 & 0.000 & - & 38.083 & 38.80 & -4404.92 \\
\hline & & & & & & & $\begin{array}{l}\mathrm{LR}^{52}=-0.10^{\mathrm{n}} \\
\mathrm{LR}^{53}=3.21^{\mathrm{ns}} \\
\mathrm{LR}^{62}=-0.02^{\mathrm{ns}} \\
\mathrm{LR}^{64}=3.29^{\text {ns }} \\
\mathrm{LR}^{73}=-0.16^{\text {ns }} \\
\mathrm{LR}^{74}=-0.16^{\text {ns }}\end{array}$ \\
\hline \multirow[t]{2}{*}{8} & 0.000 & 0.000 & 0.000 & 1.921 & 37.039 & 38.96 & -4401.72 \\
\hline & & & & & & & $\begin{aligned} \mathrm{LR}^{85} & =-0.17^{\mathrm{ns}} \\
\mathrm{LR}^{86} & =-0.25^{\text {ns }} \\
\operatorname{LR}^{87} & =3.2^{\text {ns }}\end{aligned}$ \\
\hline
\end{tabular}

$\hat{\sigma}_{a}^{2}=$ direct genetic additive variance; $\hat{\sigma}_{m}^{2}=$ maternal genetic additive variance; $\sigma_{c}^{2}=$ common litter environmental variance; $\sigma_{p}^{2}=$ permanent environmental variance; $\hat{\sigma}_{\varepsilon}^{2}=$ residual variance; and $\hat{\sigma}_{f}^{2}=$ phenotypic variance; ns = not significant; $\mathrm{LR}^{21}=\operatorname{model} 2$ with $1 ; \mathrm{LR}^{31}=$ model 3 with $1 ; \mathrm{LR}^{41}=$ model 4 with $1 ; \mathrm{LR}^{42}=$ model 4 with $2 ; \mathrm{LR}^{43}=$ model 4 with $3 ; \mathrm{LR}^{52}=$ model 5 with $2 ; \mathrm{LR}^{53}=$ model 5 with $3 ; \mathrm{LR}^{62}=$ model 6 with $2 ; \mathrm{LR}^{64}=$ model 6 with $4 ; \mathrm{LR}^{73}=$ model 7 with $3 ; \mathrm{LR}^{74}=$ model 7 with $4 ; \mathrm{LR}^{85}=$ model 8 with $5 ; \mathrm{LR}^{86}=$ model 8 with $6 ; \mathrm{LR}^{87}=$ model 8 with 7 
The causes of the maternal effect may come from the egg cytoplasm, from the intrauterine environment, from the postnatal environment, from the milk production and from the mother's ability. The latter three may be among the main causes of environmental variation among families, forming, together, the common litter effect (Robison, 1972). The causes of the common litter environmental effect, besides being related to the neonatal period - due, among so many factors, to the milk production and the mother's ability (Robison, 1972; Pita, 2000) - may also be, even if at a smaller proportion, related to gestation, once piglets of the same litter share the same prenatal environment and are, during this period, under the same influences of maternal age, health conditions of the pregnant sow and the effect of ingestion of medications and other substances which may contribute to the environmental variation among different litters.

It is further possible that, still in the intrauterine period, piglets of the same litter have a different space to develop than those of other litters. Even if these influences are not proven, it is beyond doubt that the litter size undergoes modifications with the sow`s age (Dierckx et al., 1996; Pinheiro et al., 2000; Holanda et al., 2005). According to Lima (2007), the nutrition of the fetuses is determined by the quantity of nutrients received from the mother, which depends both on the size of the placenta and on the blood flow; the latter, in turn, depends on the number of fetuses. There is a high correlation $(r=0.73)$ between size of the placenta and weight of the fetuses. Likewise, there is a high correlation $(r=0.83)$ between placental blood flow and fetal weight (De Roth and Bisaillon, 1980; Wootton et al., 1977). Piglets of larger litters weigh less because the uterine blood flow per fetus decreases with the number of fetuses (Pere et al., 1997). There is evidence that the variability of the piglets' weight is defined at the beginning of the gestation, since the smaller fetuses can already be identified at 30-35 days of gestation (Van Der Lende et al., 1990; Wise et al., 1997).

Although in the present work no influence of the common litter effect on the trait under study was found, there are other reports showing that this effect has an influence on the animals' performance throughout their life (Kaufmann et al., 2000; Zhang et al., 2000; Lukovic et al., 2003; Lukovic et al., 2004; Chimonyo et al., 2006; Cavalcante Neto et al., 2008b).
The direct additive genetic variance (Table 1) and heritability (Table 2) estimates obtained with model 1 were similar to those obtained with models which did not include the permanent environmental effect (models 3, 4 and 7) and lower than those obtained with models which did consider it (models 2, 5, 6 and 8). This finding may reinforce the concept that it is not necessary to include the maternal genetic and/or the common litter environmental effect in the genetic evaluation models for this trait.

Irgang (1994), however, found a decrease in the direct genetic additive variance and heritability when the common litter environmental effect was included in the litter size trait. Moreover, Pires (1999) reported similar results, in which the additive variance estimates showed smaller values when the maternal effect was included.

It can, however, be observed that, even if the inclusion of the permanent environmental effect was not significant according to the likelihoodratio test, 5.0 to $7.0 \%$ of the phenotypic variance was attributed to this effect, and its exclusion may have inflated the heritability coefficient, leading to confusion between non-inherited factors and the additive genetic component.

The direct heritability estimates for the farrowing interval were of low magnitude (Table 2). These results show that the phenotype is not a good indicator of the individual genotypes, and that the selection cannot be expected to provide genetic gains.

The heritability estimates obtained here using different models were lower than the one found by Irgang and Robison (1984), the value of which was 0.27. There are, however, reports of heritability estimates for this trait which are close or equal to zero. Tholen et al. (1996) worked with two pig herds in Australia and found a heritability value of 0.0 for one herd and of 0.10 for the other. Serenius and Stalder (2004) obtained estimates of 0.06 and 0.04 for the first interval between farrowings in the Landrace and Large White breeds, respectively.

Regarding repeatability estimates, it can be observed that, since the heritability was zero when the permanent environmental effect was included, it was equal to the variance proportion of the permanent environmental effect. The estimates remained the same with several models, except model 8 which considered all the random effects and in which it tended to decrease. This might be due to the sample size, i. e., the small number of 
observations may have made it difficult to perform the variance partition among the random effects considered in the model. The repeatability estimates obtained here fell outside the amplitude described by Pereira (2004), reported to be between 0.10 and 0.25 for this trait.

Table 2 - Heritability estimates for the direct additive $\left(h_{a}^{2}\right)$ and maternal $\left(h_{m}^{2}\right)$ genetic effects, and the proportion of phenotypic variance due to the common litter $\left(c^{3}\right)$ and permanent $\left(p^{2}\right)$ environmental effects, as well as the repeatability $(\mathrm{R})$ of the farrowing interval trait, according to the analysis model.

\begin{tabular}{cccccc}
\hline Modelo & \multicolumn{5}{c}{ Parâmetro } \\
& $h_{a}^{2}$ & $h_{m}^{2}$ & $c^{2}$ & $p^{2}$ & $\mathbf{R}$ \\
\hline 1 & $0.02 \pm 0.02$ & - & - & - & - \\
2 & $0.00 \pm 0.02$ & - & - & $0.07 \pm 0.04$ & 0.07 \\
3 & $0.03 \pm 0.04$ & $0.00 \pm 0.01$ & - & - & - \\
4 & $0.03 \pm 0.03$ & - & $0.00 \pm 0.02$ & - & - \\
5 & $0.00 \pm 0.03$ & $0.00 \pm 0.02$ & - & $0.07 \pm 0.04$ & 0.07 \\
6 & $0.00 \pm 0.03$ & - & $0.00 \pm 0.02$ & $0.07 \pm 0.04$ & 0.07 \\
7 & $0.02 \pm 0.03$ & $0.00 \pm 0.01$ & $0.00 \pm 0.02$ & - & - \\
8 & $0.00 \pm 0.03$ & $0.00 \pm 0.02$ & $0.00 \pm 0.02$ & $0.05 \pm 0.04$ & 0.05 \\
\hline
\end{tabular}

\section{CONCLUSION}

The heritability values obtained for the farrowing interval indicate that this trait does not present a satisfactory genetic gain in response to selection. The common litter environmental and genetic maternal effects have no influence on this trait. The permanent environment effect, however, should be considered in the genetic models for this trait, because its presence produced changes in the additive genetic variance estimates.

Further studies on more representative data should be conducted, for confirmation and validation of the results obtained here.

\section{ACKNOWLEDGEMENTS}

We acknowledge the collaboration of the Canalli brothers representing the pig farm São José in Monte Alto, SP, and of Mr. Adriano Muniz representing the pig farm São José in Cabo Verde, MG, who kindly provided the data which allowed this research to be performed.

The first author acknowledges the support of the ALBAN Programme, the European Union Programme of High Level Scholarships for Latin America (scholarship $n^{\circ}$. E07D402597BR).

\section{RESUMO}

Este trabalho teve como objetivo principal avaliar a importância da inclusão dos efeitos genético materno, comum de leitegada e de ambiente permanente no modelo de estimação de componentes de variância para a característica intervalo de parto em fêmeas suínas. Foram utilizados dados que consistiam de 1.013 observações de fêmeas Dalland (C-40), registradas em dois rebanhos. As estimativas dos componentes de variância foram realizadas pelo método da máxima verossimilhança restrita livre de derivadas. Foram testados oito modelos, que continham os efeitos fixos (grupos de contemporâneo e covariáveis) e os efeitos genético aditivo direto e residual, mas variavam quanto à inclusão dos efeitos aleatórios genético materno, ambiental comum de leitegada e ambiental permanente. $\mathrm{O}$ teste da razão de verossimilhança (LR) indicou a não necessidade da inclusão desses efeitos no modelo. No entanto observou-se que o efeito ambiental permanente causou mudança nas estimativas de herdabilidade, que variaram de 0,00 a 0,03 . Conclui-se que os valores de herdabilidade obtidos indicam que esta característica não apresentaria ganho genético como resposta à seleção. O efeito ambiental comum de leitegada e o genético materno não apresentaram influência sobre esta característica. Já o ambiental permanente, mesmo sem ter sido significativo o seu efeito pelo LR, deve ser considerado nos 
modelos genéticos para essa característica, pois sua presença causou mudança nas estimativas da variância genética aditiva.

\section{REFERENCES}

Arouca, C.L.C.; Fontes, D.O.; Ferreira, W.M.; Silva, M.A.; Pereira, F.A. (2004), Exigências de lisina, com base no conceito de proteína ideal, para suínos machos castrados, de 95 a $122 \mathrm{~kg}$, selecionados para deposição de carne magra. Arquivo Brasileiro de Medicina Veterinária e Zootecnia 56, 773-781.

Arouca, C.L.C.; D.O. Fontes, D.O; Veloso, J.A.F.; Moreira, H.F.V.; Marinho, P.C. (2005), Exigências de lisina, com base no conceito de proteína ideal, para suínos machos castrados dos 96 aos $120 \mathrm{~kg}$, selecionados para eficiência de crescimento. Arquivo Brasileiro de Medicina Veterinária e Zootecnia 57, 104-111.

Boldman, K.G.; Kriese, L.A.; Van Vleck, D.L.; Kachman, S.D. (1995), A manual for use of MTDFREML - a set of programs to obtain estimates of variances and covariances [DRAFT]. U.S. Department of Agriculture/Agriculture Research Service, Lincoln, 115 pp.

Cavalcante Neto, A. (2006), Estimativas de parâmetros genéticos e ambientais de características reprodutivas em fêmeas suínas. MSc Dissertation, Universidade Estadual Paulista, Jaboticabal, São Paulo, Brasil.

Cavalcante Neto, A.; Lui, J.F.; Sarmento, J.L.R.; Ribeiro, M.N.; Monteiro, J.M.C.; Fonseca, C.; Tonhati, H. (2008a), Efeitos genéticos e nãogenéticos sobre o intervalo de parto em fêmeas suínas no Sudeste do Brasil. Arquivo Brasileiro de Medicina Veterinária e Zootecnia 60, 1390-1395.

Cavalcante Neto, A.; Lui, J.F.; Sarmento, J.L.R.; Ribeiro, M.N.; Monteiro, J.M.C.; Fonseca, C.; Tonhati, H. (2008b), Efeitos genéticos e ambientais sobre a idade à primeira concepção de fêmeas suínas. Arquivo Brasileiro de Medicina Veterinária $e$ Zootecnia 60, 499-502.

Chen, P.; Baas, T.J.; Mabry, J.W.; Dekkers, J.C.M. and Koelher K.J. (2002), Genetic parameters and trends for lean growth rate and its components in U.S. Yorksire, Duroc, Hampshire and Landrace pigs. Journal of Animal Science 80, 2062-2070.

Chimonyo, M; Dzama, K; Bhebhe, E. (2006), Genetic determination of individual birth weight, litter weight and litter size in Mukota pigs. Livestock Science 105, 69-77.

Chiorato, A.F; Carbonell, S.A.M.; Dias, L.A.S.; Resende, M.D.V. (2008), Prediction of genotypic values and estimation of genetic parameters in common bean. Brazilian Archives of Biology and Technology 51, 465-472.
De Roth, L.; Bisaillon, A. (1980), Gestational changes in utero-placental contact surface in the sow. Paper presented at $6^{\text {th }}$ International Pig Veterinary Society Congress, Copenhagen.

Dierckx, S.M.A.G.; Ramos, A.A.; Nunes, J.R.V. (1996), Estudo de fatores de meio sobre características de leitegada em suínos. 1: Tamanho de leitegada. Veterinária e Zootecnia 8, 99-106.

Fraga, A. L.; Moreira, I.; Furlan, A.C.; Bastos, A.O.; Oliveira, R.P.; Murakami, A.E. (2008), Lysine requirement of starting barrows from two genetic groups fed on low crude protein diets. Brazilian Archives of Biology and Technology 51, 49-56.

Holanda, M.C.R; Barbosa, S. B. P.; Sampaio, I. B. M.; Santos, E.S.; Santoro, K.R. (2005), Tamanho da leitegada e pesos médios, ao nascer e aos 21 dias de idade, de leitões da raça Large White. Arquivo Brasileiro de Medicina Veterinária e Zootecnia 57, 539-544.

Irgang, R.; Robison, O.W. (1984), Heritability estimates for ages at farrowing, rebreeding interval and litter traits in swine. Journal of Animal Science 59, 67-73.

Irgang, R.; Fávero, J.A.; Kennedy, B.W. (1994), Genetic Parameters for Litter Size of Different Parities in Duroc, Landrace, and Large White Sows. Journal of Animal Science 72, 2237-2246.

Johnson, Z.B.; Chewning, J.J.; Nugent, R.A. (2002) Maternal effects on traits measured during postweaning performance test of swine from four breeds. Journal of Animal Science 80, 1470-1477.

Kaufmann, D.; Hofer, A.; Bidanel, J.P.; Künzi, N. (2000), Genetic parameters for individual birth and weaning weight for litter size of Large White pigs. Journal of Animal Breeding and Genetics 117, 121128.

Kerr, J.C.; Cameron, N.D. (1995), Reproductive performance of pigs selected for Components of efficient lean growth. Journal of Animal Science 60, 281-290.

Lima, G.J.M.M. (2007), Como manejar uma fêmea hiperprolífica e alimentar os seus leitões. Acta Scientiae Veterinariae 35, 29-36.

Luković, Z.; Malovrh, Š.; Gorjanc, G.; Uremović, M.; Kovač, M. (2003), Genetic parameters for number of piglets born alive using a random regression model. Agriculturae Conspectus Scientificus 68, 105-108.

Luković, Z.; Malovrh, Š.; Gorjanc, G.; Kovač, M. (2004), A random regression model in analysis of litter size in pigs. South African Journal of Animal Science 34, 241-248.

Mrode, R.A. (1996), Linear models for the prediction of animal breeding values. Guildford: CAB International, pp. 187

Oliveira, G.C.; Moreira, I.; Fraga, A.L.; Kutschenko, M.; Sartori, I.M. (2005), Metabolizable energy requirement for starting barrow pigs (15 to $30 \mathrm{~kg}$ ) fed 
on the ideal protein concept based diets. Brazilian Archives of Biology and Technology 48, 729-737.

Pere, M.C.; Dourmad, J. Y.; Etienne M. (1997), Effect of number of embryos in the uterine on the survival and development and on maternal metabolism. Journal of Animal Science 72, 1337-1342.

Pereira, J.C.C. (2004), Melhoramento genético aplicado à produção animal. Editora FEPMVZ, Belo Horizonte, 609 pp.

Pinheiro, M.J.P.; Galvão, R.J.D.; Bezerra Neto, F.; Espíndola, G.B. (2000), Características reprodutivas de suínos puros na região semi-árida do rio grande do norte. I. tamanho da leitegada. Caatinga 13, 19-26.

Pires, A.V.; Lopes, P. S. (2001), Efeito materno em suínos. Revista Ceres 48, 115-125.

Pires, A.V.; Lopes, P.S.; Guimarães, S.E.F.; Gomide, L.A.M.; Benevenuto Júnior, A.A.; Carmo, F.M.S. (2005), Quantitative trait loci mapping for meat quality traits in swine chromosome 6. Arquivo Brasileiro de Medicina Veterinária e Zootecnia 57, 608-615.

Pires, A.V.; Lopes, P.S.; Guimarães, S.E.F.; Guimarães, C.T.; Peixoto, J.O. (2008), Mapeamento de locos de características quantitativas associados à composição de carcaça, no cromossomo seis de suíno. Arquivo Brasileiro de Medicina Veterinária e Zootecnia 60, 725-732.

Pires, A.V. (1999), Avaliação genética de características reprodutivas em suínos. MSc Dissertation, Universidade Federal de Viçosa, Viçosa, Minas Gerais, Brasil

Pita, F.V.C. (2000), Modelos para avaliação genética e comparação de característica de desempenho para a seleção de suínos. MSc Dissertation, Universidade Estadual Paulista, Jaboticabal, São Paulo, Brasil

Rao, C.R. (1973), Linear statistical inference and its aplications. New York, John Wilwy and Sons, pp. 417-420.

Rydhmer, L.; Lundeheim, N.; Canario, L. (2008), Genetic correlations between gestation length, piglet survival and early growth. Livestock Science 115, 287-293.

Robison, O.W. (1972), The role of maternal effects in animal breeding: V. Maternal effects in swine. Journal of Animal Science 35, 1303-1315.

Roehe, R.; Kennedy, B.W. (1993), Efficiency of an approximate animal model for maternal and direct genetic effects of litter size in swine. Journal of Animal Science 71, 3251-3260.

Sarmento, J.L.R.; Torres, R.A.; Sousa, W.H.; Pereira, C.S.; Lopes, P.S.; Breda, F.C. (2006), Estimação de parâmetros genéticos para características de crescimento de ovinos Santa Inês utilizando modelos uni e multicaracterísticas. Arquivo Brasileiro de Medicina veterinária e Zootecnia 58, 581-589.

Serenius, T.; Stalder, K. J. (2004), Genetics of length of productive life and lifetime prolificacy in the Finnish Landrace and Large White pig populations. Journal of Animal Science 82, 3111-17.

Tholen, E.; Bunter, K.L.; Hermesch, S.; Graser, H.U. (1996). The genetic foundation of fitness and reproduction traits in Australian pig populations 2. Relationships between weaning to conception interval, farrowing interval, stayability, and other common reproduction and production traits. Australian Journal of Agricultural Research 47, 1275-1290.

Torres Filho, R.A. (2001), Avaliação genética de características de desempenho e reprodutivas em suínos. MSc Dissertation, Universidade Federal de Viçosa, Viçosa, Minas Gerais, Brasil

Torres Filho, R. A. ; Torres, R. A.; Lopes, P. S.; Pereira, C. S.; Euclydes, R.F.; Araújo, C.V.; Silva, M.A. (2005a), Genetic trends in the performance and reproductive traits of pigs. Genetics and Molecular Biology 28, 97-102.

Torres Filho, R.A.; Torres, R.A.; Lopes, P.S.; Pereira, C.S.; Euclydes, R.F.; Araújo, C.V.; Silva, M.A.; Breda, F.C. (2005b), Estimativas de parâmetros genéticos para características reprodutivas de suínos. Arquivo Brasileiro de Medicina Veterinária $e$ Zootecnia 57, 684-689.

Van Der Lende, T.; Hazelegen, W.; De Jager, D. (1990), Weight distribution within litters at early fetal age and at birth in relation to embryonic mortality in the pig. Livestock Production Science 26, 53-65.

Wise, T.; Roberts, R.T.; Christenson, R. K. (1997), Relationship of light and heavy fetuses to uterine position, placental weight, gestational age and fetal cholesterol concentrations. Journal of Animal Science 72, 2197-2207.

Wootton, R.; Mcfayden, I. R.; Cooper, J. E. (1977), Measurement of placental blood flow in the pig and its relation to placental and fetal weight. Biology of the Neonate 31, 333-339.

Zhang, S.; Bidanel, J.P; Burlot, T.; Legault, C.; Naveau, J. (2000), Genetic parameters and genetic trends in the Chinese $\mathrm{x}$ European Tiameslan composite pig line. I - Genetic parameters. Genetic selection and evolucion 32, 41-56. 